\title{
Properties of fly ash and metakaolín based geopolymer panels under fire resistance tests
}

\author{
Y. Luna-Galiano $\bowtie$, A. Cornejo, C. Leiva, L.F. Vilches, C. Fernández-Pereira \\ University of Seville, (Sevilla, Spain) \\ \yluna@etsi.us.es
}

\author{
Received 9 September 2014 \\ Accepted 21 January 2015 \\ Available on line 10 J une 2015
}

\begin{abstract}
This paper presents the results of a study about the effect of fire on geopolymer paste composed of fly ashes, metakaolin and sodium silicate. $2 \mathrm{~cm}$ thick, $28 \mathrm{~cm}$ high and $18 \mathrm{~cm}$ wide panels were filled with the paste obtained. After 28 days of curing at $20{ }^{\circ} \mathrm{C}$ and $45 \%$ of relative humidity, different tests were carried out in the geopolymers: physico-chemical (density, water absorption, porosity), mechanical (flexural and compressive strength), fire resistance and environmental (leaching and radioactivity). The panels manufactured have been compared with other commercial panels in order to determine the recycling possibilities of fly ashes in manufacturing new fire-insulating geopolymers. The panels obtained can be utilized for the production of interior wall materials, with a good physical, mechanical, fire resistant properties without any environmental problem.
\end{abstract}

KEYWORDS: Fly ash; Metakaolin; Mechanical properties; Pore size distribution; Temperature

Citation/Citar como: Luna-Galiano, Y.; Cornejo, A.; Leiva, C.; Vilches, L.F.; Fernández-Pereira, C. (2015) Properties of fly ash and metakaolín based geopolymer panels under fire resistance tests. Mater. Construcc. 65 [319], e059 http:/l dx.doi.org/10.3989/mc.2015.06114.

RESUMEN: Propiedades de paneles geopoliméricos basados en ceniza volante y metacaolín bajo ensayos de resistencia al fuego. Este documento presenta los resultados de un estudio sobre el efecto del fuego sobre pastas de geopolímeros compuestas de cenizas volantes, metacaolín y silicato sódico. Con la pasta obtenida se han rellenado paneles de dimensiones $2 \mathrm{~cm}$ de espesor, $28 \mathrm{~cm}$ de altura y $18 \mathrm{~cm}$ de ancho. Tras 28 días de curado a $20{ }^{\circ} \mathrm{C}$ y un $45 \%$ de humedad relativa, diferentes ensayos fueron realizados en los geopolímeros obtenidos: fisicoquímicos (densidad, absorción de agua, porosidad), mecánicos (resistencia a compresión y a flexión), de resistencia al fuego y medioambientales (lixiviación y radioactividad). Los paneles fabricados han sido comparados con paneles comerciales para determinar las posibilidades de reciclaje de las cenizas volantes para la fabricación de nuevos productos geopoliméricos con propiedades aislantes al fuego. Los paneles obtenidos pueden ser utilizados para la producción de paredes interiores, con buenas propiedades físicas, mecánicas y de resistencia al fuego sin ningún problema medioambiental.

PALABRAS CLAVE: Ceniza volante; Metacaolín; Propiedades mecánicas; Distribución de tamaño de poro; Temperatura.

Copyright: (C) 2015 CSIC. This is an open-access article distributed under the terms of the Creative Commons Attribution-Non Commercial (by-nc) Spain 3.0 License. 


\section{LIST OF NOTATION}

$\mathrm{m}_{\mathrm{i}} \quad$ is the mass

WA is the water absortion

$\mathrm{R}_{\mathrm{C}} \quad$ is the compressive strength

$\mathrm{R}_{\mathrm{FL}} \quad$ is the flexural strength

\section{INTRODUCTION}

Generation of residual combustion products is a worldwide problem with implications in the human health, the environment and the industry. Fly ash is the main coal combustion product with application in many fields, mainly in the construction industry (1) due to the good pozzolanic and cementitious properties $(2,3)$. The quantities of recycled fly ash are very small, only $44 \%$ of the ash produced in Europe in 2009 was used (see www. ecoba.com), so it is necessary to explore new applications of medium/high value, where the fly ash can be used.

Geopolymers are new materials produced in the reaction between a solid aluminosilicate and an activating solution of alkaline silicate or hydroxide at ambient temperature or at slightly high temperature (4). Geopolymers present an enormous potential as a source of products with a wide spectrum of applications (5), mainly in the construction field where geopolymers are competitive with the cement based product (6). Some of these properties are high compressive resistance and high structural integrity (7), high level of resistance to acid and salts attack $(7,8)$, low permeability (7) and good resistance to thaw-freeze cycles $(9,10)$.

Calcined kaolin has an elevated specific surface and a less crystalinity grade than the non calcined kaolin (11), so this material is widely used as source material in geopolymer (12-18). Metakaolin is used with other materials since metakaolin alone produces a weaken structure (16, 19-24). However, metakaolin is usual in the geopolymer production to manufacture hydroceramic compounds, adhesive and coating (6).

A fire resistant material is one that, for a specified time and under conditions of a standard heat intensity (25), it will not fail structurally and will not permit the side away from the fire to become hotter than a specified temperature (ambient temperature plus $160^{\circ} \mathrm{C}$ ). Some of the commercial products used for thermal insulation or passive fire protection in buildings and industrial installations have a chemical composition and chemical properties similar to those found in some ash-based products. Fly ash based geopolymers are one of them. Geopolymers, in general, present a low thermal conductivity at high temperatures (24-35) and they do no emitted toxic fume when it is heated (36), but there are no many results about the behavior of the geopolymer panels when a surface is subjected to a standard fire.
This paper is based in the study of fire resistance properties of geopolymers prepared with fly ashes and metakaolin preparing panel and subjecting them to standard fire test, continuing along the lines of other studies by this research group $(37,38)$, trying to search new ways of re-using fly ashes in manufacturing new insulating and fire-retardant products for use in fireproof doors and firewalls. Since the material is composed mainly by a waste, it has been necessary to specify any chemical or physical condition capable of inducing the release of potentially toxic compounds in the environment. For this reason, some test have been included, which have been conducted to characterize environmentally the material and some reference values are presented due to the lack in the Spanish legislation.

\section{MATERIALS AND METHODS}

\subsection{Materials}

Fly ashes (FA) from the combustion of high quality pulverized coal in one of the largest coal power plants in the South of Spain, Los Barrios (550 MWe), were used as the main aluminosilicate material. Metakaolin (MK) is prepared from kaolin as it is described by previous researchers (39). In order to compare the different properties of geopolymers with other commercial materials, samples of Ordinary Portland Cement (OPC) were prepared using commercial Portland Cement Type II (CEM II/B-L $32.5 \mathrm{~N}$ according to EN 197-1 (40)). The water/solid ratio of sample of OPC is 0.4 . The chemical composition, the vitreous phase, the bulk density and the percentage of material with a size higher than $45 \mu \mathrm{m}$ of the FA, MK and OPC are shown in Table 1.

As can be observed in Table 1, according to ASTM C618 (41), FA can be classified as class F (pozzolanic ashes). The $\mathrm{SiO}_{2}$ content of fly ash and metakaolin are over $65 \%$ and the $\mathrm{Al}_{2} \mathrm{O}_{3}$ content is $19 \%$ and $32 \%$ in fly ash and metakaolin respectively. The virtreous phase of FA and MK has been calculated as it is described in a work of Arjuan (42). The result for FA is $72.3 \%$ and for MK is $50.2 \%$. Some authors (43) mentioned that the higher the amount of amorphous phase of the fly ash, the faster the activation process and the higher the degree of reaction.

A commercial solution of sodium silicate (NaSil) was used as activating solution. The characteristics are detailed in Table 2.

\subsection{Geopolymer panel preparation}

Our goal was to come up with a product comprised mainly by fly ashes. The composition of the different panels is shown in Table 3. These compositions were selected after a previous study of the optimal compositions (44). 
TABLE 1. Chemical composition, vitreous phase, bulk density and percentage of material with a size higher than $45 \mu \mathrm{m}$ of fly ash, metakaolin and ordinary Portland cement

\begin{tabular}{|c|c|c|c|c|c|c|c|c|c|c|c|c|}
\hline & \multirow[b]{2}{*}{ Moisture (\%) } & \multirow{2}{*}{$\begin{array}{c}\text { Bulk Density } \\
\left(\mathrm{kg}^{-3} \mathrm{~m}^{-3}\right)\end{array}$} & \multirow{2}{*}{$\begin{array}{c}\% \mathrm{wt} \\
>45 \mu \mathrm{m} \\
\end{array}$} & \multirow[b]{2}{*}{ LOI (\%) } & \multirow{2}{*}{$\begin{array}{c}\text { Vitreous } \\
\text { phase (\%) }\end{array}$} & \multicolumn{7}{|c|}{ Chemical composition ( $\%$ wt) } \\
\hline & & & & & & $\mathrm{Fe}_{2} \mathrm{O}_{3}$ & $\mathrm{CaO}$ & MgO & $\mathrm{SiO}_{2}$ & $\mathrm{Al}_{2} \mathrm{O}_{3}$ & $\mathrm{Na}_{2} \mathrm{O}$ & $\mathrm{K}_{2} \mathrm{O}$ \\
\hline FA & 0.76 & 2.45 & 50 & 5.17 & 72.3 & 7.04 & 2.63 & 2.31 & 65.12 & 19.27 & 1.32 & 2.41 \\
\hline MK & 1.21 & 2.40 & 70 & - & 50.2 & 0.51 & $<0.03$ & 0.18 & 65.17 & 32.02 & 0.05 & 1.29 \\
\hline OPC & 0.97 & 3.1 & 32 & 7.05 & & 2.36 & 6.98 & 2.97 & 22.81 & 5.37 & 0.21 & 0.23 \\
\hline
\end{tabular}

TABLE 2. Characteristics of sodium silicate solution

\begin{tabular}{llllll}
\hline & $\begin{array}{c}\mathrm{SiO}_{2} \\
(\% \mathbf{w t})\end{array}$ & $\begin{array}{c}\mathrm{Na}_{2} \mathbf{O} \\
(\% \mathbf{w t})\end{array}$ & $\mathbf{S i O}_{2} / \mathrm{Na}_{2} \mathbf{O}$ & $\begin{array}{c}\text { Density } \\
\left(\mathbf{2 0}{ }^{\circ} \mathbf{C}, \mathbf{g} / \mathbf{c m}^{3}\right)\end{array}$ & $\mathbf{p H}$ \\
\hline NaSil & 27 & 8 & 3.42 & 1.346 & 11.5 \\
\hline
\end{tabular}

TABLE 3. Panels Composition (wt \%)

\begin{tabular}{lcc}
\hline & \multicolumn{2}{c}{ Composition by mass (\% wt) } \\
\cline { 2 - 3 } & G-FA & G-FA-MK \\
\hline FA & 70 & 60 \\
MK & - & 13 \\
NaSil & 30 & 27 \\
Liquid/Solid weight ratio & 0.24 & 0.21 \\
\hline
\end{tabular}

The solid components shown in the previous table were placed in a planetary mixer and were mixed until a homogeneous mixture was achieved. Then sodium silicate solution was added to the solid mixture and again was mixed until a workable and thixotropic paste was obtained. The solution and solid were mixed during 4 minutes approximately. Finally, samples were vibrated for 5 minutes in order to release bubbles. The reader can refer to Luna et al. (45) for further details.

The paste obtained was placed in $2 \mathrm{~cm}$ thick, $28 \mathrm{~cm}$ high and $18 \mathrm{~cm}$ wide panel moulds. The panels were taken out of the moulds after 24 hours and left to cure at ambient temperature for 28 days (average temperature: $20^{\circ} \mathrm{C}$; average relative humidity: $45 \%$ ). Smaller cylinder test pieces of different shapes and sizes were used in the physicochemical and mechanical tests. After this curing time, geopolymer samples were subjected to different temperatures, 300, 500 and $700{ }^{\circ} \mathrm{C}$ during 3 hours and different properties were determined.

\subsection{Methods}

\subsubsection{Physical properties}

The density ( $\rho$ ) of the mortar was measured by weight and volume (dimensions) measurements. Three specimens of each type were tested. Water absorption (WA) was measured according to European Standards EN 12859 (46).
A porosimetry study has been carried out in order to analyse the effect of these parameter in the heating behaviour of samples. A mercury intrusion porosimeter (Micromeritics Autopore IV) with a measuring pressure range from $1.02 \times 10^{-2}$ to $2.04 \times 10^{2} \mathrm{MPa}$ were used. The contact angle was $141^{\circ}$, so the measurable pore size ranged from 0.007 to $144 \mu \mathrm{m}$. Samples used had the form of pellets about $5 \mathrm{~mm}$ in size and must be dried, so samples must be stated in an oven at $105{ }^{\circ} \mathrm{C}$ during 24 hours. All analysis has been carried out two times. Mercury Intrusion Porosimetry (MIP) is a technique based on the progressive intrusion of a non-wetting substance like mercury under increasing controlled pressure. It is extensively used across a number of applications for which porosity is a critical parameter, including cementitious materials derived from Portland cement. The literature on concrete and mortars suggests that MIP may not always be highly reliable. Some researchers found that the pores measured by MIP applied on cementitious materials can be smaller than the pores observed with SEM $(47,48)$. Despite these limitations, the MIP technique is generally considered an appropriate method of analysis for porosimetry and a useful tool to examine optimal dosages and curing for comparative purposes.

\subsubsection{Mechanical properties}

The compressive strength $\left(\mathrm{R}_{\mathrm{C}}\right)$ of the pastes was also evaluated using a compressing test machine (Suzpecar, MEM-102/50 t) (ASTM E 761-86 (49)). The compressive strength tests were performed on 40-mm-high, 35-mm-diameter cylinders.

Prismatic mortar specimens were tested in three-point bending up to failure at the loading rate of $15 \mathrm{~mm} / \mathrm{min}$, with a span length of $100 \mathrm{~mm}$, according to ASTM standard test method for flexural strength $\left(\mathrm{R}_{\mathrm{FL}}\right)$ of hydraulic cement mortars (ASTM C 348-02 (50)). The test machine used to determine the flexural strength is the same used to determine the compressive strength (Suzpecar, MEM-102/50 t), with the necessary equipment for this test. Two samples were used to measure the flexural strength and four to determine the compressive strength. The variation coefficients of different test were $<1 \%$. 


\subsubsection{Fire insulating properties}

The standard fire-resistance test described in Spanish regulation EN 1363-1 (51), which is similar to other widely-used international standards, has been used. To simulate the conditions of exposure to fire, the regulation requires that one of the sides of the protective material be exposed to heat according to a standard temperature curve defined by the equation [1]:

$$
\mathrm{T}=20+345 \cdot \log 10(8 \mathrm{t}+1)
$$

where $\mathrm{T}$ is the oven temperature for the tests $\left({ }^{\circ} \mathrm{C}\right)$ and $t$ is the time (minutes) from the beginning of the test.

To study the insulating capacity of the panels, a special oven was used so that the moulded panels could be subjected to the standard fire resistance test mentioned above. This furnace allowed us to record the surface temperature of the exposed surface (hot surface, $T_{\text {in }}$ ) of the panel by means of an S-type thermocouple inside the oven, which was used to regulate the temperature of the oven by means of a proportional controller in order to produce the standard temperature curve. On the unexposed surface (cold surface, $\mathrm{T}_{\text {out }}$ ), the temperature was registered by means of a Pt-100 probe with a stainless steel contact surface (52).

In order to analyse the insulating capacity of the panels in a way similar to that recommended by the Spanish standards, the time necessary for Tout to reach $180{ }^{\circ} \mathrm{C}\left(\mathrm{t}_{180}\right)$ has been considered as a reference value for studying this property in $20 \mathrm{~mm}$-thick panels.

With the aim of measuring the energy absorbed by the different materials, we used the differential scanning calorimetry (DSC) technique. Thus, 5-mm-diameter, 3-mm-thick samples placed in nonhermetic aluminium containers, were subjected to a heating program of $2^{\circ} \mathrm{C} \cdot \mathrm{min}^{-1}$ in a TA DSC 2920 Instrument, from $30{ }^{\circ} \mathrm{C}$ to $400{ }^{\circ} \mathrm{C}$, using nitrogen as purging gas. The energy absorbed by the pastes between $100-170^{\circ} \mathrm{C}$ in the DSC tests (in $\mathrm{J} \cdot \mathrm{g}^{-1}$ ) was obtained by integrating the area underneath the peaks in DSC test (53).

\subsection{Environmental study}

Given that fly ash is a residual material, an environmental study has been carried out to characterize the product more completely in order to make a better evaluation about its possible uses as construction materials. The products developed in the present work must guarantee a low toxicity level, which is often assessed through leaching and radiological studies.

The leaching study involved subjecting the material to one of the most commonly used tests for monolith samples in the waste management field in Europe, the NEN 7345 diffusion test or tank leaching test (54). The leachates were measured in the Analytical Services of the University of Seville (CITIUS) using ICP-OES equipment.

By-products of coal combustion contain enhanced concentration of the natural radionuclides ${ }^{40} \mathrm{~K},{ }^{226} \mathrm{Ra}$ and ${ }^{232} \mathrm{Th}$ and their decay products. These radionuclides emit alpha particles, beta particles, and gamma rays, and therefore they are a source of ionizing radiation (55). Exposure to such radiation is considered to pose a hazard to human health. Building products based on coal ashes are classified by the relevant European Commission Directorate for Radiation Protection as materials with enhanced radioactivity (56). The radioactivity of samples was measured in the analytical service of the University of Seville (CITIUS). A well-type HPGe detector from Canberra with a relative efficiency of $30 \%$ and a crystal volume of $160 \mathrm{~cm}^{3}$ was used. The samples obtained were collected into a cylindrical holder and sealed with paraffin film. Each sample was measured for at least 25 days after the sample was prepared, to establish secular equilibrium between ${ }^{226} \mathrm{Ra}$ and ${ }^{232} \mathrm{Th}$ and their respective radioactive progeny. The ${ }^{226} \mathrm{Ra}$ and ${ }^{232} \mathrm{Th}$ contents were measured through the photopeaks of their daughters, ${ }^{214} \mathrm{Bi}(1.760 \mathrm{MeV})$ and ${ }^{208} \mathrm{Tl}(2.614 \mathrm{MeV})$, respectively, while the ${ }^{40} \mathrm{~K}$ content was measured directly via its $1.460 \mathrm{MeV}$ peak.

\section{RESULTS AND DISCUSSION}

\subsection{Physical and mechanical properties}

Table 4 shows some of the physical parameters of these materials, as well as the mechanical properties.

As it can be seen in Table 4, geopolymer G-FA-MK has a higher porosity than G-FA. Several authors $(29,57)$ used a quantitative model based on Micromechanics to study open porosity and found that alkali-activated fly ash is less porous $(30 \% \mathrm{v} / \mathrm{v})$ than alkali activated metakaolin $(40 \% \mathrm{v} / \mathrm{v})$, and they were both less porous than cementitious materials such as ordinary Portland cement. According to Table 1, the particle size distribution of FA is finer than MK. This thicker granulometry of metakaolin affects to the pore size distribution, creating more porous zones between non-attacked particles. Besides, there must be taken into account that a geopolymer with two aluminosilicate sources can form a more heterogeneous material, which can influence the porosity and the mechanical properties.

Figure 1 represents the pore size distribution of G-FA-MK and G-FA. Both geopolymers show a wide pore distribution, in all range of sizes $(0.03-100 \mu \mathrm{m})$, but the pore volume in G-FA-MK is higher than in G-FA, mainly in the range of capillary 
TABLE 4. Physical and mechanical properties

\begin{tabular}{lccccc}
\hline & *Porosity $\left(\mathbf{m L} \cdot \mathbf{g}^{-\mathbf{1}}\right)$ & Density $\left(\mathbf{k g} \cdot \mathbf{m}^{-3}\right)$ & WA $(\%)$ & $\mathbf{R}_{\mathrm{C}}(\mathbf{M P a})$ & $\mathbf{R}_{\mathrm{FL}}(\mathbf{M P a})$ \\
\hline G-FA & 0.0264 & 1541 & 16.2 & 25.4 & 8.3 \\
G-FA-MK & 0.0840 & 1502 & 16.9 & 14.3 & 6.1 \\
OPC & & 1782 & 14.0 & 32.5 & 6.9 \\
\hline
\end{tabular}

*These value of porosity are calculated with geopolymer dryed at $105^{\circ} \mathrm{C}$

pores $(0.1-10 \mu \mathrm{m})$, pores refer to the space left by the water that does not react during the hydration of cement (58).

As can be seen in Table 4, the geopolymers G-FA and G-FA-MK are less dense than the OPC type II, which is due to the lower bulk density $(\mathrm{MK} \cong \mathrm{FA}<\mathrm{OPC})$ and the thicker particle size distribution $(\mathrm{MK}>\mathrm{FA}>\mathrm{OPC})$. In any case, the geopolymers can be classified as high density panels $\left(>1100 \mathrm{~kg} \cdot \mathrm{m}^{-3}\right)$ in accordance with EN 12859 (46). Regarding the water absorption, the results are consistent with the density of samples, since the water absorption is inversely proportional to the density.

The mechanical properties measured at 28 days in geopolymers and OPC are too shown in Table 4. As can be seen, sample with OPC shows the highest compressive strength $(32.5 \mathrm{MPa})$ and intermediate value of flexural strength $(6.9 \mathrm{MPa})$. Regarding the geopolymers, the G-FA present better compressive (25.4 MPa) and flexural (8.3 MPa) strength than the G-FA-MK geopolymer (compressive strength of $14.3 \mathrm{MPa}$ ). The compressive resistance decrease almost a $50 \%$, that is, metakaolin based geopolymers have a poor resistant structure. This is the reason because the metakaolin is used in gepolymer with other aluminium and silicon source materials $(16,19-23)$. It must be taken into account that the amorphous phase of MK $(50.2 \%)$ is lower than the FA $(72.3 \%)$, so the activation of the fly ash during the geopolymerization reaction is slower (43), with the consequent lower compression strength. Besides, a material with greater porosity produces

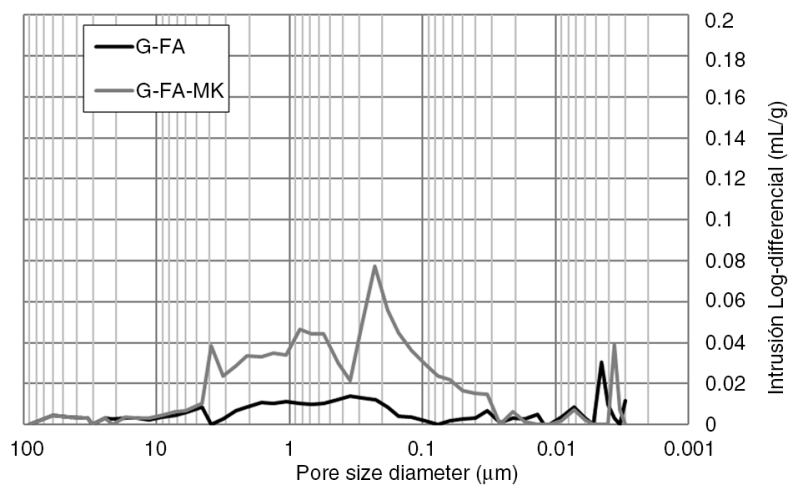

FIGURE 1. Pore size distribution of G-FA and G-FA-MK geopolymer. fewer contact areas between particles and increasing stress and crack propagation (38).

\subsection{Fire insulating properties}

The fire insulating capacity of both geopolymers and OPC are showed in Figure 2.

When the surface of a porous medium with water content in its different forms (free, adsorbed, crystalized, etc.) is exposed to fire (high temperatures), part of the water evaporates, which generates overpressure in the pores of the material. Consequently, the evaporated water is transported from the fire exposed surface as a result of a pressure gradient to the interior of the material, which is cooler, and the water condenses again. A liquid film is thus formed which is progressively displaced toward the unexposed part. Thus, the water content of the material causes an evaporation plateau in the temperature profile of the unexposed side (temperature vs. time) since the pressure gradients do not significantly influence the saturation pressure of the liquid water in the interphase (37). Therefore, a higher evaporation plateau produces greater insulating capacity (51). The other factor that affect to the insulating capacity is the slope of the curve (before and after the evaporation plateau), which is proportional to the thermal diffusivity of the material (37). As it can be observed in Figure 2, the behaviour of the G-FA panel is different to the G-FA-MK panel. Firstly, the evaporation plateau of the geopolymer with MK is shorter and it happened at higher temperature than the geopolymer without MK. In order to understand this behaviour, the energy absorbed by differential scanning calorimetry (DSC) technique is determined for the three mixtures (OPC, G-FA and G-FA-MK) and represented in Figure 3.

The area under the peak of the DSC curve of the geopolymer G-FA-MK is lower than the geopolymer G-FA, between 50 and $200{ }^{\circ} \mathrm{C}$. This is in accordance with the shorter evaporation plateau shown by G-FA-MK (Figure 2). The absorption of energy by the pastes responds to the content and the chemical form in which water is present in them (free, adsorbed, crystalized, etc.), and the evaporation plateau is proportional to this area (53). The G-FA-MK geopolymer has a lower water content than the G-FA geopolymer, so its area (under the DSC curve) is smaller. The peak of DSC curve for G-FA-MK is slightly move to high temperatures 


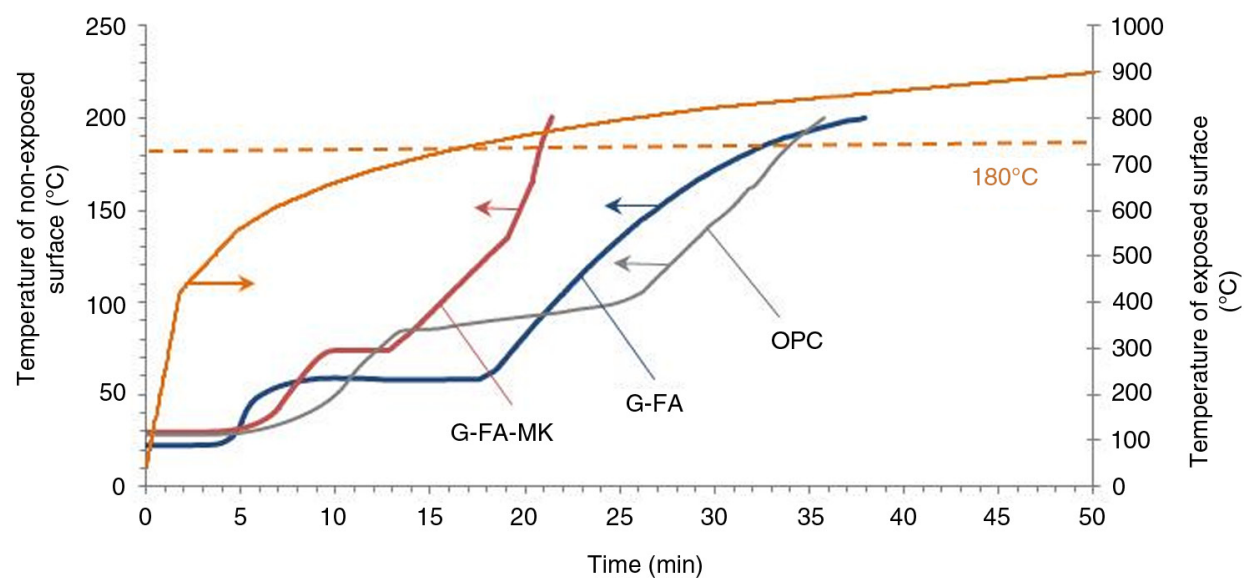

FIGURE 2. Fire insulating of the different geopolymers products.

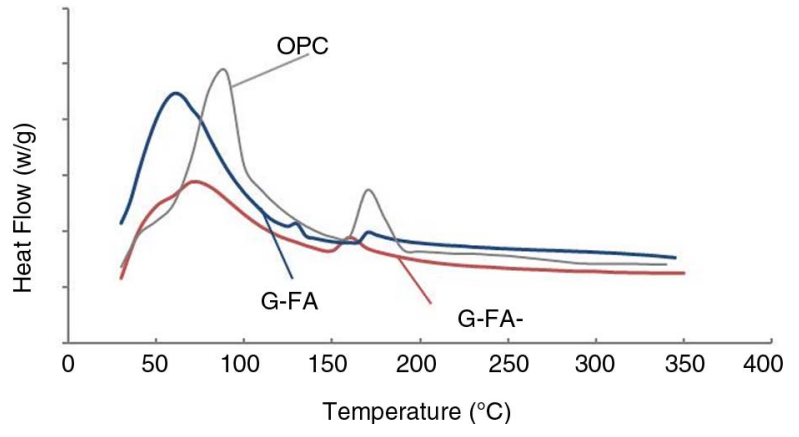

FIGURE 3. DSC of of the different geopolymers products.

regarding the G-FA curve, possibly due to the different forms of water in the geopolymers with and without MK and it is related with the change of the evaporation plateau temperature in Figure 2. The OPC presents a greater area in DSC test and its evaporation plateau is longer too.

Secondly, other aspect to take into account in Figure 2 is the change of slope after the evaporation plateau in some materials, as G-FA-MK and OPC. However, the G-FA does not present this fast increment. In this geopolymer the slope of the curve decreases along the time (after the evaporation plateau). The thermal diffusivity after the evaporation plateau of different materials can be compared in Figure 3, if the heat flow absorbed in DSC test increase, the thermal diffusivity of the material decreases, and the slope after the evaporation plateau will be smaller, increasing the insulating capacity (53), this is the reason because G-FA present a similar fire insulating capacity than OPC, although G-FA presents a lower evaporation plateau. The thermal diffusivity of the compounds produced during the hydration in the geopolymerization reaction is lower than OPC compounds (37).

Besides, it must be emphasized the no emission of gas and toxic fumes during the fire resistance test.
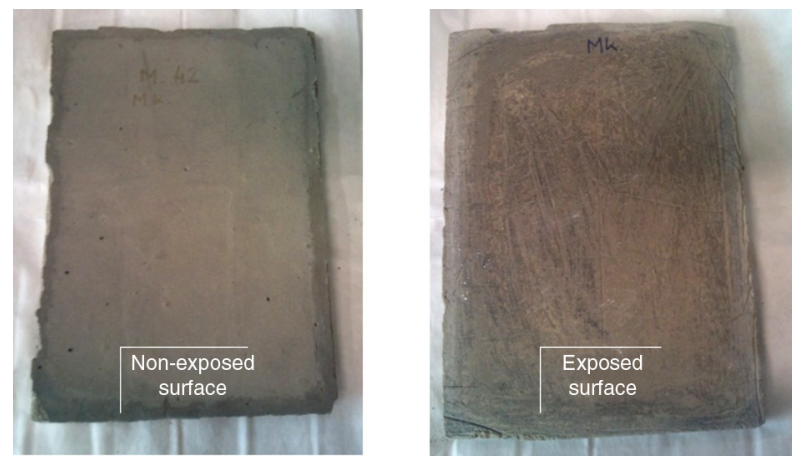

FIgUre 4. Photograph of G-FA after the fire test.

All the compositions kept the integrity of the panel after the fire test (Figure 4).

\subsection{Study of the evolution of mass, porosity and compressive strength with the temperature}

This study has been carried out in order to assess the evolution of density, compressive strength and porosity during the exposure at high temperatures. Samples were placed in an oven at 105, 300, 500 and $700{ }^{\circ} \mathrm{C}$ during three hours. After this time, samples were subjected to a slow cooling. Weight and compressive strength were measured after the test (that is, at a temperature $\mathrm{T})\left(\mathrm{m}_{\mathrm{T}}\right.$ and $\left.\mathrm{R}_{\mathrm{CT}}\right)$, the values were compared with the same parameters of one sample without thermal treatment (that is, at $\left.20{ }^{\circ} \mathrm{C}\right)\left(\mathrm{m}_{20}\right.$ and $\left.\mathrm{R}_{\mathrm{C} 20}\right)$ and relative value were calculated. Porosity is determined too at different temperatures.

\subsubsection{Mass loss}

Figure 5 shows the evolution of the relative residual mass $\left(\mathrm{m}_{\mathrm{T}} / \mathrm{m}_{20}\right)$ with the temperature of geopolymer G-FA and G-FA-MK. 


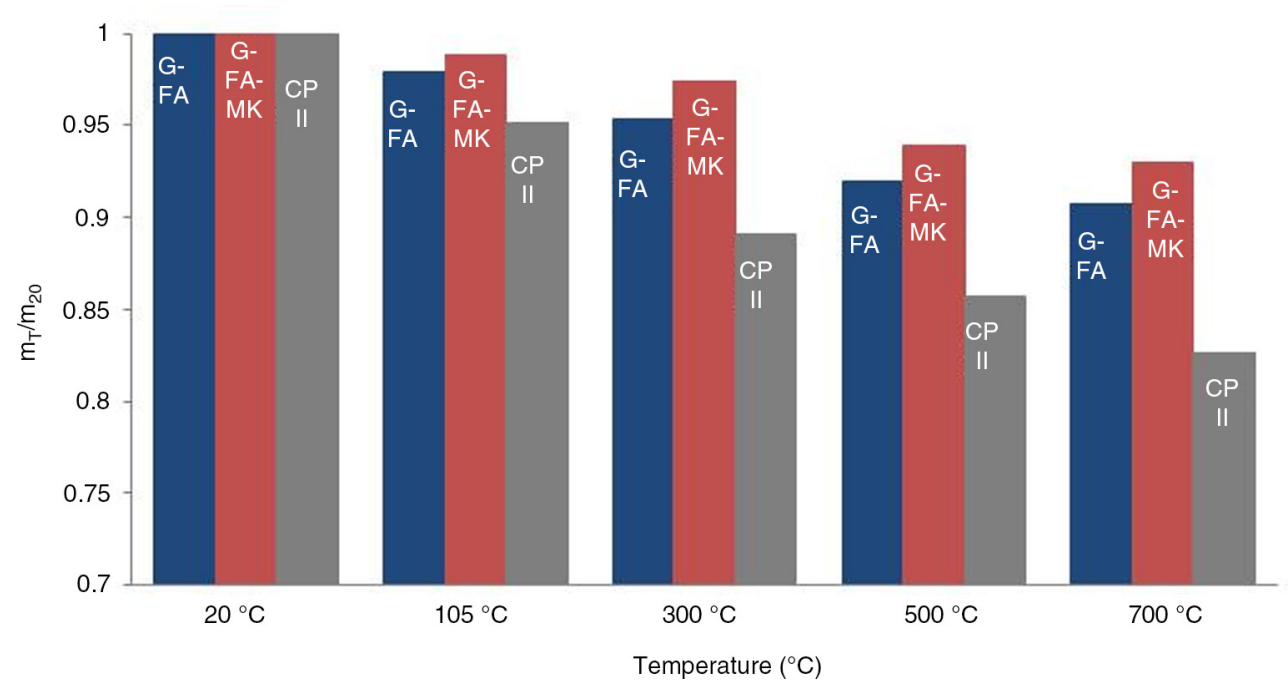

FIGURE 5. Evolution of relative residual mass with the temperature.

The trend of both geopolymers (with or without MK) is identical. There is a continuous loss of weight up $700{ }^{\circ} \mathrm{C}$. The weight loss at $105^{\circ} \mathrm{C}$ is principally due to the free water, and it is lower in G-FA-MK than in G-FA. This is due to the moisture content since moisture content in G-FA-MK $(1.9 \%)$ is less than in G-FA $(2.9 \%)$. In the range $105-300{ }^{\circ} \mathrm{C}$, the loss of mass is again lower in geopolymer G-FA-MK. As it can be seen in the fire resistance results, Figure 2, the absorbed water content of G-FA-MK is less than G-FA (the evaporation plateau of the geopolymer with $\mathrm{MK}$ is shorter) in a temperature in the range of $50-200{ }^{\circ} \mathrm{C}$, as it is showed in DSC figure too (Figure 3). This is the reason because the mass loss at $300{ }^{\circ} \mathrm{C}$ of G-FA-MK is less than in G-FA. Between 300 and $700{ }^{\circ} \mathrm{C}$, the mass subsequently decreased due to dehydration of water from aluminosilicates gel, but it is very similar in both geopolymers (27). In any case, sample prepared with OPC present the highest loss of mass of all ( $20 \%$ of loss), which can indicate the high integrity of geopolymers after the exposure at high temperature.

\subsubsection{Porosity and pore size distribution}

Table 5 shows the evolution of porosity with the temperature.

TABLE 5. Evolution of porosity with the temperature

\begin{tabular}{lcccc}
\hline & \multicolumn{4}{c}{ Porosity $\left(\mathbf{m L} \cdot \mathbf{g}^{-1}\right)$} \\
\cline { 2 - 5 } Temperature $\left({ }^{\circ} \mathbf{C}\right)$ & 105 & 300 & 500 & 700 \\
\hline G-FA & 0.0264 & 0.0688 & 0.2324 & 0.2672 \\
G-FA-MK & 0.0840 & 0.0850 & 0.3044 & 0.3055 \\
\hline
\end{tabular}

As can be seen in Table 5, an increment in the porosity is occurred during the heating of samples between 105 and $700{ }^{\circ} \mathrm{C}$. This increment is deeper in geopolymer G-FA than in geopolymer G-FA-MK. In order to understand this behaviour, the curve Log-differencial intrusion volume versus pore size diameter is represented. Pore size distribution of geopolymer without metakaolin (G-FA) is showed in Figure 6.

This geopolymer shows a slight increment of the porosity in the range $105-300{ }^{\circ} \mathrm{C}$, from $0.0264 \mathrm{~mL} \cdot \mathrm{g}^{-1}$ at $105^{\circ} \mathrm{C}$ to $0.0688 \mathrm{~mL} \cdot \mathrm{g}^{-1}$ at $300^{\circ} \mathrm{C}$ (Table 5) that is correlated with the graph Figure 6 since in this figure geopolymer at $300^{\circ} \mathrm{C}$ show a slight increment of the intrusion volume in the range of $0.5-4 \mu \mathrm{m}$ (capillary pores $(0.2-3 \mu \mathrm{m}))$ of pore size when it is compared with the geopolymer at $105{ }^{\circ} \mathrm{C}$. The highest increment of porosity is obtained in the range of temperature $300-500{ }^{\circ} \mathrm{C}$, from $0.0688 \mathrm{~mL} \cdot \mathrm{g}^{-1}$ at $300{ }^{\circ} \mathrm{C}$ to $0.2324 \mathrm{~mL} \cdot \mathrm{g}^{-1}$ at $500{ }^{\circ} \mathrm{C}$ (an increment of $\left.70 \%\right)$. In this interval, a change in pore structure is observed since a high increment of pore volume is presented by the geopolymer G-FA, with a big peak between 0.5 to $4 \mu \mathrm{m}$, that is, with an increment of number of pores during heating since 300 to $500{ }^{\circ} \mathrm{C}$. The increment of pore volume in the range $300-500{ }^{\circ} \mathrm{C}$ is possibly due to a substantial shrinkage occurred as the temperature increase above to $300{ }^{\circ} \mathrm{C}$, as it is commented by Rovnanik (33). This author indicated that the drastic shrinkage is related to the thermal damage sustained by the geopolymer paste. During heating between 500 to $700{ }^{\circ} \mathrm{C}$, other slight increment of porosity is produced $\left(0.2324 \mathrm{~mL} \cdot \mathrm{g}^{-1}\right.$ at $500{ }^{\circ} \mathrm{C}$ to $0.2672 \mathrm{~mL} \cdot \mathrm{g}^{-1}$ at $700{ }^{\circ} \mathrm{C}$ ). As it can be seen in Figure 6, a slight change in pore distribution occurred between 500 and $700{ }^{\circ} \mathrm{C}$ since a shift to the higher pore size is observed, since $0.5-4 \mu \mathrm{m}$ to 


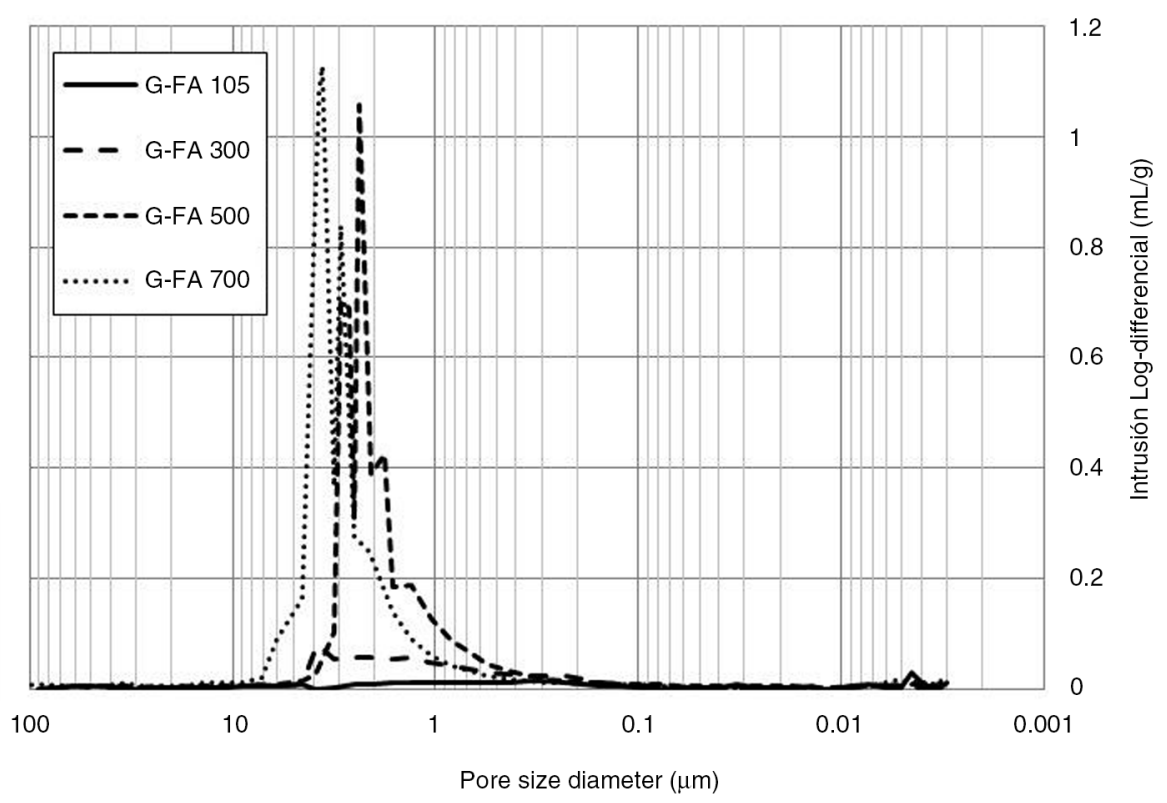

FIGURE 6. Geopolymer G-FA. Evolution of pores size distribution with the temperature.

1-7 $\mu \mathrm{m}$, towards larger capillary pores $(1-10 \mu \mathrm{m})$. At $500{ }^{\circ} \mathrm{C}$, the capillary pores dominated the structure of matrix but at $700{ }^{\circ} \mathrm{C}$, the structure is dominated by large pores.

Pore size distribution of geopolymer with metakaolin (G-FA-MK) is represented in Figure 7.

This graph shows a slightly different behaviour than the geopolymer without metakaolin. Firstly, there no exist differences between the porosity at 105 and $300{ }^{\circ} \mathrm{C}$ with a value of porosity of $0.084 \mathrm{~mL} \cdot \mathrm{g}^{-1}$ at $105^{\circ} \mathrm{C}$ and $0.085 \mathrm{~mL} \cdot \mathrm{g}^{-1}$ at $300{ }^{\circ} \mathrm{C}$ (Table 5) and in Figure 7 the curves of pore size distribution is similar. In the range $300-500{ }^{\circ} \mathrm{C}$, the porosity increase, from $0.085 \mathrm{~mL} \cdot \mathrm{g}^{-1}$ at $300{ }^{\circ} \mathrm{C}$ to $0.3044 \mathrm{~mL} \cdot \mathrm{g}^{-1}$ at $500{ }^{\circ} \mathrm{C}$ (an increment of $72.1 \%$, similar than the geopolymer G-FA) producing an increment of the pore volume (Figure 7), with a large peak between 0.2 to $3 \mu \mathrm{m}$, zone of capillary pores. Again an increment of number of pores is produce during heating since 300 to $500{ }^{\circ} \mathrm{C}$. During heating between 500 to $700{ }^{\circ} \mathrm{C}$, there are no differences in the porosity $\left(0.3044 \mathrm{~mL} \cdot \mathrm{g}^{-1}\right.$ at $500{ }^{\circ} \mathrm{C}$ to $0,3055 \mathrm{~mL} \cdot \mathrm{g}^{-1}$ at $700{ }^{\circ} \mathrm{C}$ ), with little differences in the pore size distribution of the structure of matrix.

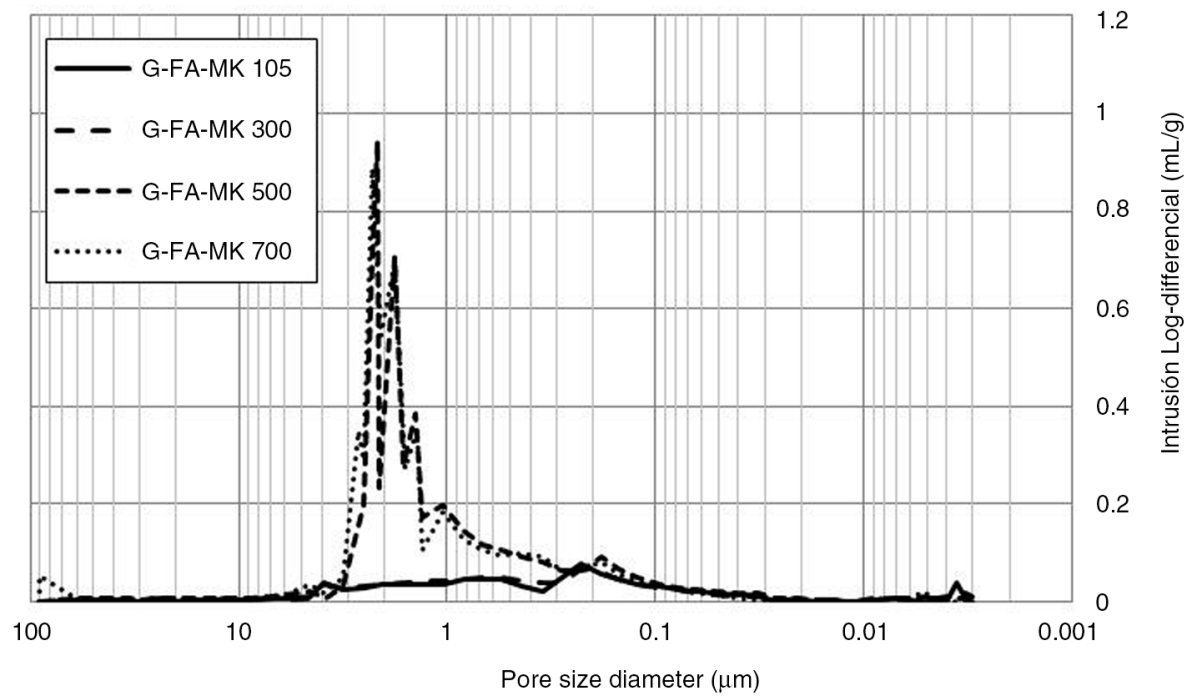

FigurE 7. Geopolymer G-FA-MK. Evolution of pores size distribution with the temperature. 
Having into account the evolution of porosity with the temperature of both geopolymers, detailed in Table 5, geopolymer without metakaolin shows a lower porosity than geopolymer with metakaolin. As can be seen in Figures 6 and 7, the geopolymer G-FA shows a shift of pore size distribution to the larger pores, although the pore size distribution of geopolymer G-FA-MK present high amount of pore in the range $0.06-3 \mu \mathrm{m}$ at $300-500{ }^{\circ} \mathrm{C}$, which can explain the higher values of porosity of this last geopolymer.

\subsubsection{Compressive strength}

Figure 8 shows the evolution of the relative residual compressive strength $\left(\mathrm{R}_{\mathrm{CT}} / \mathrm{R}_{\mathrm{C} 20}\right)$ after the exposure to different temperatures.

Figure 8 depicts an increase-decrease trend similar to that shown in previous studies by other authors (27-30). The compressive strength is increased until $300{ }^{\circ} \mathrm{C}$, these increasing is probably attributed to promotion of polycondensation between chain-like geopolymer gels (32). The geopolymers attain their maximum strength at $300{ }^{\circ} \mathrm{C}(21.8 \mathrm{MPa}$ for G-FA-MK and 33.5 MPa for G-FA). Subsequently, the compressive strength gradually decreased at higher temperatures. This phenomenon is related to the large increase in porosity between $300^{\circ}$ and $500^{\circ} \mathrm{C}$, as it was shown in Table 5 .

As can be seen, porosity of both geopolymers increases with the temperature, from $105{ }^{\circ} \mathrm{C}$ to $700{ }^{\circ} \mathrm{C}$. The highest porosity increment is in the range of 300 to $500{ }^{\circ} \mathrm{C}$, range in which compressive strength shows the highest decrement, mainly in geopolymer G-FA-MK. However, in the range
500 to $700{ }^{\circ} \mathrm{C}$, the increment of porosity is lower than in the range 300 to $500{ }^{\circ} \mathrm{C}$, producing a lower diminution of compressive strength. This behaviour is too observed by other researcher (33), but in alkaline activated slags.

Figure 8 shows clearly that geopolymers have higher residual compressive strengths than OPC specimens (21.1 MPa for G-FA, 14.88 MPa for G-FA-MK at $500{ }^{\circ} \mathrm{C}$ and $18.57 \mathrm{MPa}$ for G-FA, $14.05 \mathrm{MPa}$ for G-FA-MK at $700{ }^{\circ} \mathrm{C}$ ), OPC specimens dropped considerably at high temperatures $\left(29 \mathrm{MPa}\right.$ at $105^{\circ} \mathrm{C}, 17 \mathrm{MPa}$ at $300^{\circ} \mathrm{C}$, and finally the OPC sample was spalled at $500{ }^{\circ} \mathrm{C}$ ). This strength deterioration of OPC is attributed to the $\mathrm{Ca}(\mathrm{OH})_{2}$ decomposition that occurs at about $400{ }^{\circ} \mathrm{C}$, which produce a spalling process (34).

\subsection{Environmental study}

\subsubsection{NEN 7345 tank leaching test}

Given the scarcity of standards existing in Spain regarding the reuse of secondary materials in the construction sector, the Dutch regulations stated in the Decree on Soil Quality (DSQ) (59) have also been considered. The DSQ contains rules related to the use of different materials in construction aimed at preventing pollution of the soil and surface waters.

Since the geopolymers studied are used as monoliths, it seems reasonable to pay more attention to the leaching of the conformed product. Thus, Table 6 shows the results of the leachability study carried out according to the NEN 7345 diffusion test of test pieces taken from the panel. The NEN 7345 tank

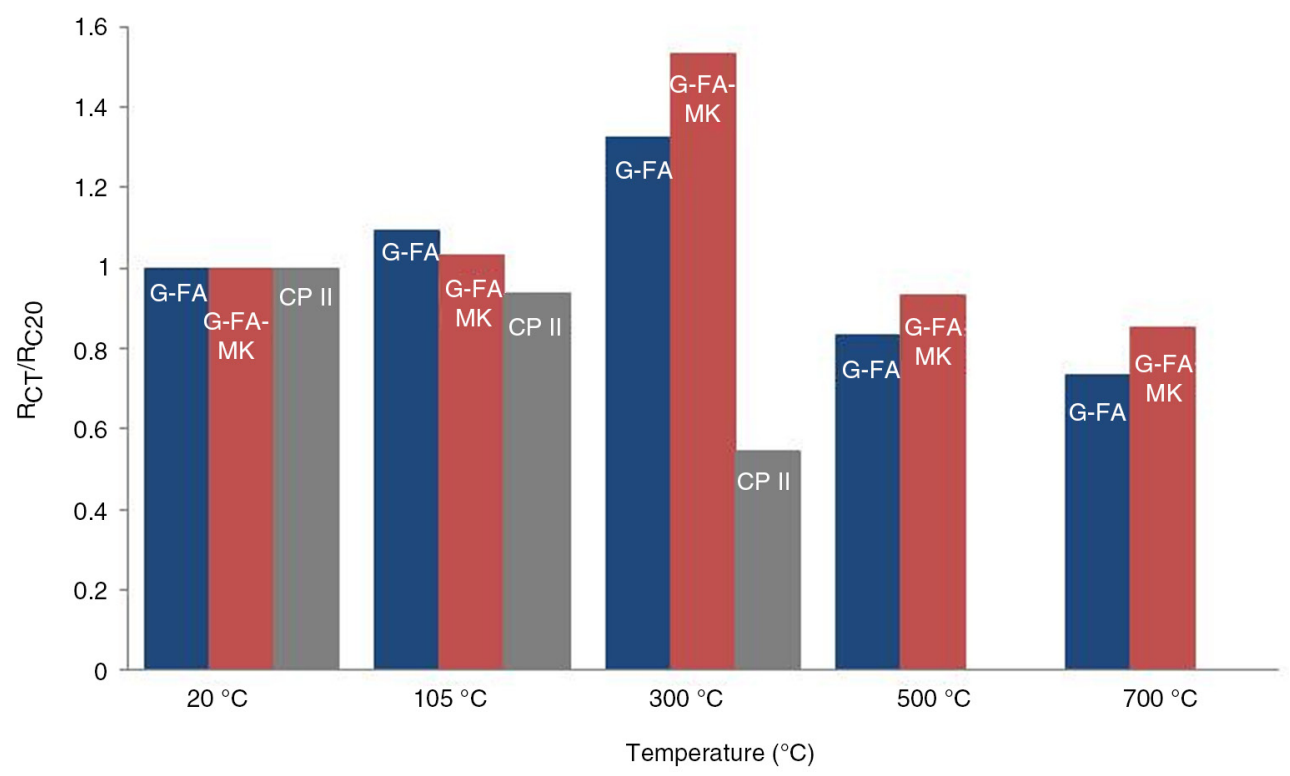

FIGURE 8. Evolution of relative residual compressive strength with the temperature. 
TABLE 6. Leaching test NEN 7345 results $\left(\mathrm{mg} / \mathrm{m}^{2}\right)$ of geopolymers and OPC compared with the DSQ limits

\begin{tabular}{|c|c|c|c|c|}
\hline & \multicolumn{3}{|c|}{ Cummulative concentration $\left(\mathrm{mg} \cdot \mathrm{m}^{-2}\right)$} & \multirow{2}{*}{$\begin{array}{c}\text { DSQ limits } \\
\left(\mathrm{mg} \cdot \mathrm{m}^{-2}\right)\end{array}$} \\
\hline & G-FA & G-FA-MK & OPC & \\
\hline $\mathrm{Hg}$ & $<1.0$ & $<1.0$ & $<1.0$ & 1.4 \\
\hline Sn & $<1.6$ & $<11.6$ & 3.0 & 50 \\
\hline $\mathbf{P b}$ & $<3.1$ & $<3.1$ & $<2.8$ & 400 \\
\hline $\mathbf{B a}$ & 2.1 & $<0.5$ & 2.6 & 1500 \\
\hline Cd & $<0.5$ & $<0.5$ & $<0.3$ & 3.8 \\
\hline Sb & $<2.6$ & $<2.6$ & $<1.8$ & 8.7 \\
\hline Co & $<0.5$ & $<0.5$ & $<1.2$ & 60 \\
\hline $\mathrm{Cr}$ & 9.4 & 7.3 & 2.9 & 120 \\
\hline $\mathbf{V}$ & 41.2 & 35.0 & $<2.2$ & 320 \\
\hline As & 9.9 & 9.9 & 2.8 & 260 \\
\hline Mo & 21.4 & 17.2 & $<2.5$ & 144 \\
\hline $\mathbf{N i}$ & $<0.5$ & $<0.5$ & $<1$ & 81 \\
\hline Zn & 6.3 & 2.6 & $<0.1$ & 800 \\
\hline $\mathrm{Cu}$ & $<0.5$ & $<0.5$ & $<0.3$ & 98 \\
\hline $\mathrm{Cl}^{-}$ & 608.7 & 401.4 & - & 18000 \\
\hline $\mathbf{F}^{-}$ & 35.7 & 21.8 & - & 1300 \\
\hline $\mathrm{SO}_{4}^{=}$ & 8300.0 & 6107.7 & - & 27000 \\
\hline
\end{tabular}

leaching test is the test prescribed by the DSQ for bound or shaped materials.

Table 6 contains the cumulative concentrations after 64 days of leaching of some metals in the leachate. As shown in this table, all the heavy metals analyzed are under the detection limits, and no important environmental problems are expected for the use of the panels developed in this study according to DSQ. The use of metakaolin instead of fly ashes has no changed the leaching content of the geopolymers in the proportions analysed in this work.

\subsubsection{Radioactivity tests}

The radiological safety of building materials based on coal combustion waste is ensured by complying with limitations set out by international recommendations and national legislations $(55,56$, 60-62). In Spain, as already mentioned in the leaching tests section, there is no legislation for this kind of product. International recommendations (56) allow choosing an effective dose increment constraint in the range $0.3-1.0 \mathrm{~m} \mathrm{~Sv} \cdot \mathrm{y}^{-1}$ for prolonged exposure to natural radiation by a member of the public. The effective dose also takes into account, in addition to the energy absorbed by the body due to exposure to radiation, the relative biological harm and the susceptibility to harm of different biological tissues.

The activity concentrations of radionuclides ${ }^{226} \mathrm{Ra},{ }^{232} \mathrm{Th}$, and ${ }^{40} \mathrm{~K}$ in the samples of geopolymers tested are presented in Table 7. Results show that the activity concentrations of ${ }^{226} \mathrm{Ra},{ }^{232} \mathrm{Th}$ and ${ }^{40} \mathrm{~K}$ are similar in geopolymers with and without MK, and are higher in geopolymers than in OPC. In any case, the activities of the different radionuclides are below the European recommendations (56).

For practical goals, the evaluation of the compliance of a specific building material with the limits of international recommendations (56) is carried out using the activity concentration index "I". This index is expressed in terms of activity concentrations of the three major natural radionuclides: ${ }^{226} \mathrm{Ra}$, ${ }^{232} \mathrm{Th}$, and ${ }^{40} \mathrm{~K}$, according to the equation [2]:

$$
\mathrm{I}=\mathrm{CRa}-226 / 300+\mathrm{CTh}-232 / 200+\mathrm{CK}-40 / 3000
$$

where CRa-226, CTh-232, CK-40 are the activity concentrations of ${ }^{226} \mathrm{Ra},{ }^{232} \mathrm{Th}$ and ${ }^{40} \mathrm{~K}$ in Bq$\cdot \mathrm{kg}^{-1}$ in the building material tested. To comply with the regulations (based on the annual dose increment constraint of $0.3 \mathrm{mSv} \cdot \mathrm{y}^{-1}$ ) the activity concentration index calculated for the product tested must comply with the criterion: I $£ 1.0$ (56). The results of Table 7 confirm a potential for industrial use of these geopolymers because "I" is under this criterion.

\section{CONCLUSIONS}

The geopolymers with a high proportion of fly ashes has potential to be used as plates which can be an alternative to fire-resistant commercial plates with Portland.

Geopolymer with metakaolin shows lower density and water absorption and higher porosity than the geopolymer without metakaolin. The mechanical

TABLE 7. Activity concentrations $\left(\mathrm{Bq} \cdot \mathrm{kg}^{-1}\right)$ of radionuclides ${ }^{226} \mathrm{Ra},{ }^{232} \mathrm{Th}$, and ${ }^{40} \mathrm{~K}$ and Activity concentration index (I) of geopolymers

\begin{tabular}{lrrrrc}
\hline Activity concentrations & G-FA & G-FA-MK & OPC & $\begin{array}{c}\text { Typical activity concentration } \\
\text { of concrete (53) }\end{array}$ & $\begin{array}{c}\text { Maximun activity } \\
\text { concentration of concrete (53) }\end{array}$ \\
\hline${ }^{226} \mathrm{Ra}$ & 49 & 49 & 4.0 & 40 & 240 \\
${ }^{232} \mathrm{Th}$ & 23 & 19 & 7.0 & 30 & 190 \\
${ }^{40} \mathrm{~K}$ & 368 & 340 & 29 & 400 & 1600 \\
$\mathrm{I}$ & 0.40 & 0.37 & 0.06 & 0.41 & - \\
\hline
\end{tabular}


strength of a 28-day-old block with metakaolin is lower than the geopolymer without metakaolin.

The fire resistance is higher in geopolymers with only fly ashes, and it is very similar to the ordinary Portland cement, but without spalling that occurs in cement. Geopolymers present a high compressive strength at elevated temperatures than ordinary Portland cement. The evolution of porosity during heating is the key to understand the evolution of the compressive resistance with the temperature since between 300 to $500{ }^{\circ} \mathrm{C}$ a high amount of pores is created due to the shrinkage occurred.

From an environmental point of view the geopolymers with fly ashes have no presented problems regarding leaching and radioactivity according to some general regulations, although a more specific environmental legislation would be desirable to facilitate the recycling of waste as a construction material.

\section{PRACTICAL RELEVANCE AND POTENTIAL APPLICATIONS}

The work presents an experimental study about the effect of the elevated temperature in fly ashmetakaolin based geopolymers. Various tests were carried out in the geopolymers: physical (density, volumetric expansion), mechanical (flexural and compressive strength) and environmental (leaching and radioactivity test) in order to complete the study and prove. The main objective of the research is to obtain a material with a real application. The panels manufactured have been compared with other commercial panels in order to determine the recycling possibilities of fly ashes as geopolymers in this application. It can also be concluded that the panels obtained in this work can be utilized for the production of interior wall materials, with a good physical, mechanical, fire resistant properties without any environmental problem.

The aim of this paper is to analyze the fire resistance of geopolymers and composites largely by fly ash, so that from the information provided, it is easy to start a production on an industrial scale.

To do this, the panels have been tested for fire resistance according to European standards. Further, a characterization of the variation of the compressive strength at high temperatures has been conducted, with the aim of analyzing the mechanical behavior of the material during a fire, according to changes in the porosity of the material.

Finally, since the material is composed mainly by wastes, an extensive environmental characterization of the material has been carried out, many European standards require that building materials with wastes must specify any chemical or physical condition likely to cause the release of potentially toxic compounds in the environment (leaching and radiological safety), but this question is not analyzed in many studies about the reuse of wastes in construction materials.

\section{ACKNOWLEDGEMENTS}

The authors would like to acknowledge the financial support for this research by the Spanish Ministry of Science and Technology with European FEDER funds, under GEOPOL project (CTM2010-19917).

\section{REFERENCES}

1. González, A.; Navia, R.; Moreno, N. (2009) Fly ashes from coal and petroleum coke combustion: current and innovative potential applications. Waste. Manage. Res. 27, 976-987. http://dx.doi.org/10.1177/0734242X09103190.

2. Anderson, M.; Jones, R.; McCarthy, M. (2008) Established uses of combustion residues. In Combustion Residues. Current, Novel and Renewable Applications (Cox M, Nugteren $\mathrm{H}$ and Janssen-Jurkovicová M (eds)) Wiley and Sons Ltd. Chichester, England. http://dx.doi.org/10.1002/ 9780470094440.ch2.

3. Ahmaruzzaman, M. (2010) A review on the utilization of fly ash. Progr. Energ. Combust. 36, 327-363. http://dx.doi. org/10.1016/j.pecs.2009.11.003.

4. Davidovits, J. (1991) Geopolymers: inorganic polymeric new materials. J. Therm. Anal. 37, 1633-1656. http://dx.doi. org/10.1007/BF01912193.

5. Palomo, A.; Krivenko, P.; Garcia-Lodeiro, I.; Kavalerova, E.; Maltseva, O.; Fernández-Jiménez, A. (2014) A review on alkaline activation: new analytical perspectives. Mater. Construcc. 64 [315], e022. http://dx.doi.org/10.3989/mc. 2014.00314

6. Duxson, P.; Provis, J.L.; Lukey, G.C.; Van Deventer, J.S.J. (2007) The role of inorganic polymer technology in the development of 'green concrete'. Cem. Concr. Res. 37, 1590-1597. http://dx.doi.org/10.1016/j.cemconres.2007. 08.018 .

7. Van Jaarsveld, J.G.S.; Van Deventer, J.S.J.; Lorenzen, L. (1997) The potencial use of geopolymeric materials to immobilise toxic metals: Part I. Theory and applications. Miner. Eng. 10 [7], 659-669. http://dx.doi.org/10.1016/ S0892-6875(97)00046-0.

8. Bakharev, T. (2005) Resistance of geopolymer materials to acid attack. Cem. Concr. Res. 35 [4], 658-670. http://dx.doi. org/10.1016/j.cemconres.2004.06.005.

9. Davidovits, J. (1994) Properties of geopolymers cements. In: Proceedings of First International Conference on Alkaline Cements and Concretes (Krivenko P (ed)). Kiev, Ukraine. 131-149.

10. Sindhunata. (2006) The mechanisms and kinetics of fly ash based geopolymerization. Ph.D. Thesis of University of Melbourne. Australia.

11. Van Deventer, J.S.J.; Lukey, G.C.; Xu, H. (2006) Effect of curing temperature and silicate concentration on fly ash-based geopolimerization. Ind. Eng. Chem. Res. 45, 3559-3568. http://dx.doi.org/10.1021/ie051251p.

12. Duxson, P.; Mallicoat, S.W.; Lukey, G.C.; Kriven, W.M.; Van Deventer, J.S.J. (2007) The effect of alkali and $\mathrm{Si} / \mathrm{Al}$ ratio on the development of mechanical properties of metakaolin-based geopolymers. Colloids. Surfaces. A. 292, 8-20. http://dx.doi.org/10.1016/j.colsurfa.2006.05.044.

13. Palomo, A.; Blanco-Varela, M.T.; Granizo, M.L.; Puertas, F.; Vazquez, T.; Grutzek, M.W. (1999) Chemical stability on cementitious materials based on metakaolin. Cem. Concr. Res. 29 [7], 997-1004. http://dx.doi.org/10.1016/ S0008-8846(99)00074-5.

14. Provis, J.L.; Duxson, P.; Van Deventer, J.S.J.; Lukey, G.C. (2005) The Role of Mathematical Modelling and Gel Chemistry in Advancing Geopolymer Technology. Chem. Eng. Res. Des. 83 [7], 853-860. http://dx.doi.org/10.1205/ cherd.04329.

15. Singh, P.S.; Trigg, M.; Burgar, I.; Bastow, T. (2005) Geopolymer formation processes at room temperature studied by 29Si and 27Al MAS-NMR. Mater. Sci. Eng. A. 396 [1-2], 392-402. http://dx.doi.org/10.1016/j.msea. 2005.02 .002 . 
16. Xu, H.; Van Deventer, J.S.J. (2003) Effect of source materials on geopolymerisation. Ind. Eng. Chem. Res. 42, 1698-1706. http://dx.doi.org/10.1021/ie0206958.

17. Van Jaarsveld, J.G.S.; Van Deventer, J.S.J. (1999) The effects of metal contaminants on the formation and properties of waste-based geopolymers. Cem. Concr. Res. 29 [8], 1189-1200. http://dx.doi.org/10.1016/S0008-8846(99)00032-0.

18. Van Jaarsveld, J.G.S.; Van Deventer, J.S.J.; Schwartzman, A. (1999) The potencial use of geopolymeric materials to immobilise toxic metals: Part II. Materials and leaching characteristics. Miner. Eng. 12 [1], 75-91. http://dx.doi. org/10.1016/S0892-6875(98)00121-6.

19. Bankowski, P.; Zou, L.; Hodges, R. (2004) Reduction of metal leaching in brown coal fly ash using geopolymers. J. Hazard. Mater. 114 [1-3], 59-67. http://dx.doi.org/ 10.1016/j.jhazmat.2004.06.034.

20. Bankowski, P.; Zou, L.; Hodges, R. (2004) Using inorganic polymer to reduce leach rates of metals from brown coal fly ash. Miner. Eng. 17, 159-166. http://dx.doi.org/10.1016/j. mineng.2003.10.024

21. Wu, H-C.; Sun, P. (2007) New building materials from fly ash-based lightweight inorganic polymer. Constr. Build. Mater. 21 [1], 211-217. http://dx.doi.org/10.1016/j. conbuildmat.2005.06.052.

22. Swanepoel, J.C.; Strydom, C.A. (2002) Utilization of fly ash in a geopolymeric material. Appl. Geochem. 17, 1143-1148. doi: 10.1016/S0883-2927(02)00005-7.

23. Van Jaarsveld, J.G.S.; Van Deventer, J.S.J.; Lorenzen, L. (1998) Factors affecting the immobilisation of metals in geopolymerized fly ash. Metall. Mater. Trans. B 29, 659-669/283-291. http://dx.doi.org/10.1007/s11663-998-0032-z.

24. Davidovits, J. (1991) Geopolymers: inorganic polymeric new materials. J. Therm. Anal. 37, 1633-1656. http://dx.doi. org/10.1007/BF01912193.

25. Lyon, R.E.; Balaguru, P.N.; Foden, A.; Sorathia, U.; Davidovits, J.; Davidovits, M. (1997) Fire-resistant aluminosilicate composites. Fire Mater. 21 [2], 67-73. http://dx.doi. org/10.1002/(SICI)1099-1018(199703)21:2<67::AIDFAM $596>3.0 . \mathrm{CO} ; 2-\mathrm{N}$

26. Duxson, P.; Lukey, G.C.; Van Deventer, J.S.J. (2006) Thermal evolution of metakaolin geopolimer: part 1-physical evolution. J. Non-Cryst. Solids. 352 [52-54], 5541-5555. http://dx.doi.org/10.1016/j.jnoncrysol.2006.09.019.

27. Zuda, L.; Rovnaník, P.; Bayer, P.; Cerny, R. (2007) Thermal Properties of Alkali-activated Slag Subjected to High Temperatures. J. Build. Phys. 30, 337-350. http://dx.doi. org/10.1177/1744259106075234.

28. Pan, Z.; Sanjayan, J.G. (2010) Stress-strain behaviour and abrupt loss of stiffness of geopolymer at elevated temperatures. Cem. Concr. Comp. 32, 657-664. http:// dx.doi.org/10.1016/j.cemconcomp.2010.07.010

29. Kong, D.; Sanjayan, J.G.; Sagoe-Crentsil, K. (2007) Comparative performance of geopolymers made with metakaolin and fly ash after exposure to elevated temperatures. Cem. Concr. Res. 37 [12], 1583-1589. http:// dx.doi.org/10.1016/j.cemconres.2007.08.021.

30. Kong, D.; Sanjayan, J.G. (2008) Damage behavior of geopolymer composites exposed to elevated temperatures. Cem. Concr. Comp. 30 [10], 986-91. http://dx.doi.org/ 10.1016/j.cemconcomp.2008.08.001.

31. Dombrowski, K.; Buchwald, A.; Weil, M. (2007) The influence of calcium content on the structure and thermal performance of fly ash based geopolymers. J. Mater. Sci. 42 [3], 3033-3043. http://dx.doi.org/10.1007/s10853-006-0532-7.

32. Zhang, Y.J.; Li, S.; Wang, Y.C.; De Long, X. (2012) Microstructural and strength evolutions of geopolymer composite reinforced by resin exposed to elevated temperature. J. Non-Cryst. Solids. 358 [3], 620-624. http://dx.doi.org/ 10.1016/j.jnoncrysol.2011.11.006.

33. Rovnaník, P.; Bayer, P.; Rovnaníková, P. (2013) Characterization of alkali activated slag paste after exposure to high temperatures. Constr. Build. Mater. 47, 1479-1487. http://dx.doi.org/10.1016/j.conbuildmat.2013.06.070.

34. Peng, G-F.; Huang, Z-S. (2008) Change in microstructure of hardened cement paste subjected to elevated temperatures.
Constr. Build. Mater. 22 [4], 593-599. http://dx.doi.org/ 10.1016/j.conbuildmat.2006.11.002.

35. Cheng, T.W.; Chiu, J.P. (2003) Fire-resistant geopolymer produced by granulated blast furnace slag. Minerals Engineering 16, 205-210. http://dx.doi.org/10.1016/S08926875(03)00008-6.

36. Duxson, P.; Lukey, G.C.; Van Deventer, J.S.J. (2006) Thermal Conductivity of Metakaolin Geopolymers Used as a First Approximation for Determining Gel Interconnectivity. Ind. Eng. Chem. Res. 45 [23], 7781-7788. http://dx.doi.org/10.1021/ ie060187o.

37. Vilches, L.F.; Leiva, C.; Vale, J.; Fernández Pereira, C.; Olivares, J. (2005) Coal Fly Ash-Containing Sprayed Mortar for Passive Fire Protection of Steel Sections. Mater. Construcc. 55, 25-37. http://dx.doi.org/10.3989/mc.2005. v55.i279.196.

38. Leiva, C.; Vilches, L.F.; Fernández Pereira, C.; Vale, J. (2005) Influence of the type of ash on the fire resistance characteristics of ash-enriched mortars. Fuel. 84, 1433-1439. http:// dx.doi.org/10.1016/j.fuel.2004.08.031

39. Madani, A.; Aznar, A.; Sanz, J.; Serratosa, J.M. (1990) Silicon-29 and aluminum-27 NMR study of zeolite formation from alkali-leached kaolinites: influence of thermal preactivation. J. Phys. Chem. 94 [2], 760-765. http://dx.doi. org/10.1021/j100365a046.

40. EN (2000) 197-1: Cement - Part 1: Composition, specifications and conformity criteria for common cements. European committee for standarisation. Brussels, Belgium.

41. ASTM (2005) C 618-05, Standard Specification for Coal Fly Ash and Raw or Calcined Natural Pozzolan for Use in Concrete. ASTM International, USA.

42. Arjuan, P.; Silbee, M.R.; Roy, D.M. (1997) Quantitative determination of the crystalline and amorphous phases in low calcium fly ash. In: Proceedings of the 10th international congress of the chemistry of cement, Gothenburg, Sweeden, 3, 2-6. ISBN: 91630549739789163054976.

43. Fernández-Jiménez, A.; Palomo, A. (2003) Characterization of fly ashes. Potential reactivity as alkaline cements. Fuel. 82 [8], 2259-2265. http://dx.doi.org/10.1016/S00162361(03)00194-7.

44. Luna, Y.; Cornejo, A.; Leiva, C.; Fernández Pereira, C.; Vilches, L. (2012) Fire resistance of geopolymers with fly ashes and metakaolin as aluminosilicate sources. In: Proceeding of the International Congress of Chemical Engineering ANQUE 2012. ISBN: 978-84-695-3536-3.

45. Luna, Y.; Fernández Pereira, C.; Vale, J. (2010) Waste Stabilization/Solidification (S/S) of Eaf Dust Using Fly Ash-Based Geopolymers. Influence of Carbonation on the Stabilized Solids. Coal. Combust. Gasification. Products. 2, 1-8. http://dx.doi.org/10.4177/CCGP-D-09-00015.1.

46. EN (2001) 12859: Gypsum panels. Definitions, requirements and test methods. European committee for standarisation. Brussels, Belgium.

47. Lloyd, R.R.; Provis, J.L.; Smeaton, K.J.; Van Deventer J.S.J. (2009) Spatial distribution of pores in fly ash-based inorganic polymer gels visualised by Wood's metal intrusion, Micropor. Mesopor. Mater. 126, 32-39. http://dx.doi. org/10.1016/j.micromeso.2009.05.016.

48. Diamond, S. (2000) Mercury porosimetry. An inappropriate method for the measurement of pore size distributions in cement-based materials, Cem. Concr. Res. 30, 1517-1525. http://dx.doi.org/10.1016/S0008-8846(00)00370-7.

49. ASTM (1991) E 761-86: Compressive strength of the fireresistive material applied to structural member. ASTM International, USA.

50. ASTM (2002) C 348-02: Standard test method for flexural strength and modulus of hydraulic cement mortars. ASTM International, USA.

51. EN (2000) 1363-1: Fire resistance test. Part 1: General requirements. European committee for standarisation. Brussels, Belgium.

52. Leiva, C.; García Arenas, C.; Vilches, L.F.; Vale, J.; Fernández Pereira, C. (2010) Use of FGD gypsum in fire resistant panels. Waste. Manage. 3, 1123-1129. http://dx.doi. org/10.1016/j.wasman.2010.01.028. 
53. Vilches, L.F.; Leiva, C.; Vale, J.; Fernández Pereira, C. (2005) Insulating capacity of fly ash pastes used for passive protection against fire. Cem. Concr. Comp. 27, 776-781. http://dx.doi.org/10.1016/j.cemconcomp.2005.03.001.

54. NEN 7345 (1995) Determination of the Leaching of Inorganic Components from Building and Monolithic Waste Materials with the Diffusion Test. Leaching Characteristics of Soil and Stony Building and Waste Materials-Leaching test. Netherlands Normalisation Institute, Delft, The Netherlands

55. Nisnevich, M.; Sirotin, G.; Schlesinger, T.; Eshel, Y. (2008) Radiological safety aspects of utilizing coal ashes for production of lightweight concrete. Fuel. 87, 1610-1616. http:// dx.doi.org/10.1016/j.fuel.2007.07.031.

56. ECRP 112 (1999) Radiological Protection Principles Concerning the Natural Radioactivity of Building Materials. European Commission Radiation Protection 112.

57. Smilauer, V.; Hlavacek, P.; Skvara, F.; Sulc, R.; Kopecky, L.; Nemecek, J. (2011) Micromechanical multiscale model for alkali activation of fly ash and metakaolin. J. Mater. Sci.
46 [20], 6545-6555. http://dx.doi.org/10.1007/s10853-011$5601-\mathrm{X}$

58. Ma, Y.; Hu, J.; Ye, G. (2012) Effect of activating solution on mechanical strength, reaction rate, mineralogy, and microstructure of alkali-activated fly ash. J. Mater. Sci. 47 [11], 4568-4578. http://dx.doi.org/10.1007/s10853-012-6316-3.

59. Decree on Soil Quality. Staatsblad 2007. Besluit van 22 november 2007, houdende regels inzake de kwaliteit van de bodem (Besluit bodemkwaliteit). Staatsblad, 2007, nr 469.

60. ECRP 88 Recommendations for the Implementation of Title VII of the European Basic Safety Standards Directive (BSS) Concerning Significant Increase in Exposure due to Natural Radiation Sources. European Commission Radiation Protection 88 (1997).

61. Council Directive 96/29 (1996). Official Journal of the European Communities L159.

62. ICRP 29 Protection of the Public in Situations of Prolonged Radiation Exposure. Annals of the ICRP 29 (1-2), ICRP Pub. 82. New York, Pergamon Press (1999). 